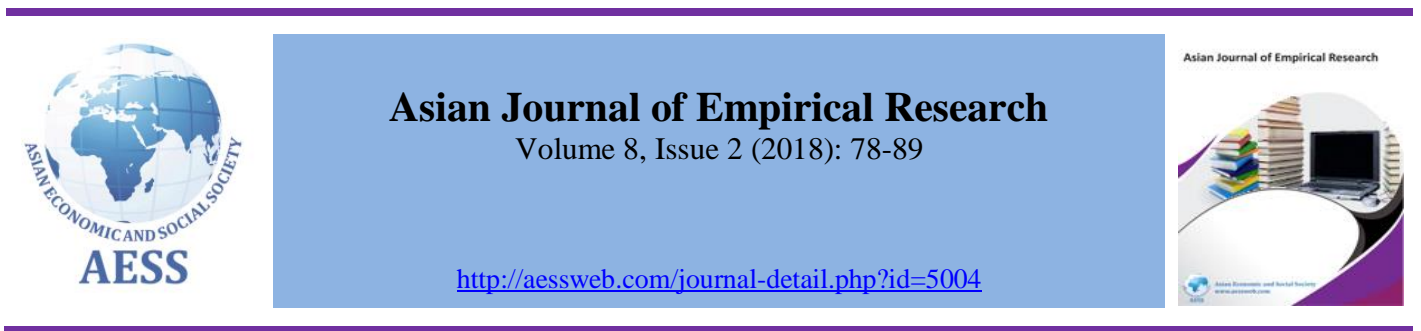

\title{
Analyzing the service quality of private secondary schools in Sri Lanka from student's perspective with special reference to a reputed private secondary school in Colombo
}

\section{N. S. Jayawardena}

Department of Management Studies, National School of Business Management, Colombo, Sri Lanka $\bowtie$ sadamalijayawardena@gmail.com

ARTICLE HISTORY:

Received: 02-Jan-2018

Accepted: 20-Feb-2018

Online available: 07-Mar2018

\section{Keywords:}

SERVQUAL model,

Private secondary schools,

Student satisfaction,

Service quality

\begin{abstract}
The proposed study analyses the service quality levels of private secondary school education in Sri Lanka from the perspective of students. The aim of the research is to study service quality levels offered in private secondary schools to improve the quality of education levels in Sri Lanka. For this purpose a main private secondary school was used as the case study. It helps to develop strategies to school management and the respective administrative authorities. Furthermore, the policy implications based on the final findings of this particular research will be used to enhance the required productivity levels and quality standards of Sri Lankan private secondary schools. This is a quantitative study and intends to use the sample size of 400 students out of the total body of over 2500 student population. The survey questionnaire derived from SERVQUAL model which consists of the five dimensions which are reliability, responsiveness, empathy, assurance and tangibles. Data been analyzed using the 7 point Likert scale and the SPSS statistical software to reach the ultimate findings based on the service quality dimensions.
\end{abstract}

\section{Contribution/ Originality}

The current study helps to identify the current service quality levels offered in private secondary schools, in order to improve the overall quality of education in Sri Lanka. For this purpose a major private secondary school was used as the case scenario. Furthermore, the findings of this paper would be beneficial for policy making and decision making in "Higher Education Sector" of Sri Lanka.

DOI: 10.18488/journal.1007/2018.7.2/1007.2.78.89

ISSN (P): 2306-983X, ISSN (E): 2224-4425

CrossMark

How to cite: N. S. Jayawardena (2018). Analyzing the service quality of private secondary schools in Sri Lanka from student's perspective with special reference to a reputed private secondary school in Colombo. Asian Journal of Empirical Research, 8(2), 78-89.

(C) 2018 Asian Economic and Social Society. All rights reserved 


\section{INTRODUCTION}

In Sri Lanka, secondary school education quality is a topic, which is crucial and essential to majority. According to the Sri Lankan culture majority of the parents struggles to get the admission into a top rank government school in Colombo and the number of admissions outreaches the available resources each year. All the rejected applicants are then struggling for a reputed private school. So this is a vital topic where majority of the rejected applicants and those who couldn't attend to a public school struggles for. In Sri Lanka, most of the private schools are comprise of one CEO/manager of the top level with an average of the 4 to 5 director board members and 15 to 20 frontline counter staff and supporting staff for accounting work, administration and HR etc. The top level personnel are only responsible for policymaking, public relations management and the human resource management as well as the legal contractual matters and agreements etc. According to the Sri Lankan culture of the private secondary school education the cost cutting is done via service quality cut downs. As a result decreasing quality levels of education could happen. Therefore, disputes and conflicts occur between the students, teachers and parents who are the main victims of the system. Thus, this study is conducted in order to analyses the root cause of the problem which is the service being rendered by the schools needs to be analyzed and improved, so the ultimate problems and disputes could be overwhelmed. Finally, to the entire education system it is the crucial factor, which guides the future generation of the country. Furthermore, the overall productivity level depends on the school management system.

\subsection{Research aims}

The main aim of this research is to get an understanding on the current quality levels of the service rendered by the private secondary schools in Sri Lanka using 5 different factors under the SERVQUAL model which are reliability which is the effort towards delivering the prompt service, tangibles which means the existing facilities in the school and the usage of new equipment, technology, and the physical appearance of the service rendering personnel, responsiveness which means the prompt inner feeling to support the customers at the required time, assurance means the competence, politeness, credibility and ensuring the safety of the workforce in the company, empathy means including access, communication, understanding the customer. Here in this proposed study, the current levels of service quality being analyzed so as to improve the whole structure of the school using 5 different variables.

This research is solely based on the below four main questions. Throughout the study it seeks the answers mainly focusing the below given questions.

RQ1: The main method to improve current service quality of private secondary schools in Sri Lanka using the feedback of teachers, students and parents as a whole?

RQ2: The perceptions of students in private secondary schools have on the service quality been offered by the school teachers?

RQ3: In what ways the service quality can be improved in the secondary private schools?

RQ4: What are the policies and strategies that can be furthermore implemented using the relevant findings of the research?

\subsection{Significance of this study}

This research reflects the essential areas which should improve within the school management. First of all, this study identified the key areas which should improve in terms of current level of service quality. This study aims in improving the quality levels been provided to students in achieving their educational targets. As service is intangible and subject to measure exactly, in order to provide quality service it is essential that there should be an alignment in the values and perceptions of the customers with those staff delivering the service and the managers who provide the service specifications. The research identified key areas to be improved that enhances the future levels of service quality in terms of the five dimensions of SERVQUL model. It also helps to make better policies and strategic decisions as well as it also identifies the areas to be improved and the areas which lacks attention by the school administration. 


\section{LITERATURE REVIEW}

\subsection{Private secondary school education system in Sri Lanka}

In the past, 'restructuring' was a common scenario for many school systems in the educational industry, Therefore, it is explicit that there is a substantial decentralization in policy making and decision making system in schools. Education of developing countries are hard to change as the relevant policies are sometimes inapplicable and not done in the practical world due to resource constraints and the unavailability of knowledge and technology in rural areas in Sri Lanka.

Currently, there are 98 private schools, but unfortunately zero private secondary schools in Northern Province and North Central province in Sri Lanka. In the year 2010, the total population of the students who studied in the private secondary schools were around 117,000.Hence the teachers were only 6000 which is a 1:19.5 ratio among teachers to children.

The Sri Lankan government ensures that the school text books being provided for students in Grade 1 to Grade 11 respectively. The total number of private schools are increasing at an alarming rate, with the growth of upper-middle class population. Private schools in Sri Lanka, consist of superior and upto-date facilities than public institutions, but are not free of charge. To attend, you must have sufficient financial means to pay the fees, though semi-government schools now exist. These are for families who desire a private education for their children, but do not have the financial means to pay. The most famous private schools are located in the capital, Colombo (Guide, 2008).

\subsection{Models of service quality}

When considering the ultimate delivery process in any service it is vital that the measuring point of service quality where each customer contact is an opportunity to satisfy or dissatisfy them. Consumer insight on quality levels are complex process in nature. According to a study of Dotchin and Oakland 1994 , it is defined most frequently as the "a degree to which a service meets client's needs or expectations". Furthermore, Parasuraman et al. (1985), provides a grading through SERVQUAL model five dimensions as described above.

For the purpose of offering high level of service quality the company should constantly measure and monitor the quality of service been offered to customers. After identifying the relevant competitive position of the company the senior management can fill the service level gaps and the required areas by the customers in enhancing the quality levels of the service. This will leads to gain the ultimate competitive advantage over rivals in the market.

SERVQUAL model is more important as a performance instrument that developed to quantity customer's insights on service superiority and described in detailed manner by Parasuraman et al. (1985). As mentioned above Reliability, Responsiveness, Assurance, Empathy, Tangibles can be taken as measuring variables of quality levels in the company.

SERVQUAL model is more important as a performance instrument that developed to quantity customer's insights on service superiority and described in detailed manner by Parasuraman et al. (1985). As mentioned above Reliability, Responsiveness, Assurance, Empathy, Tangibles can be taken as measuring variables of quality levels in the schools. "According to the recent updates it is said that the education ministry in Sri Lanka realized that it is a must to take appropriate steps to contrivance a series of special programs and workshops with the purpose of generating an appropriate atmosphere for education through better social background, healthy mind and body. Accordingly the ministry of education in Sri Lanka has named the month of June from 1st to 30th as the "Month of School Children Protection" and a series of various programs have been planned in relation to the protection of children within the school premises and as well as outside of the school" (Ministry of Education, 2016).

Accordingly with the support of Sri Lankan government it is crucial to engage with more investigations in order to reinforce the existing education system in Sri Lanka. Finally, majority of the 
Sri Lankans are facing with the issue of improper education due to low quality standards of education offered. So this is a practical and very useful topic where the single perspective been considered in analyzing and improving the service levels.

Gronroos (1990) develops the service triangle model. It is also called as the service-marketing model. Gronroos (1990) divide the model to 3 main groups, which, track disjointedly but accumulates well to accomplish establishment's targets. These 3 groups are the most vital in administrative and legislative context as either these three are separate without either one of them business cannot operate effectively. When considering those three groups company (top management), employees, customers can be taken.

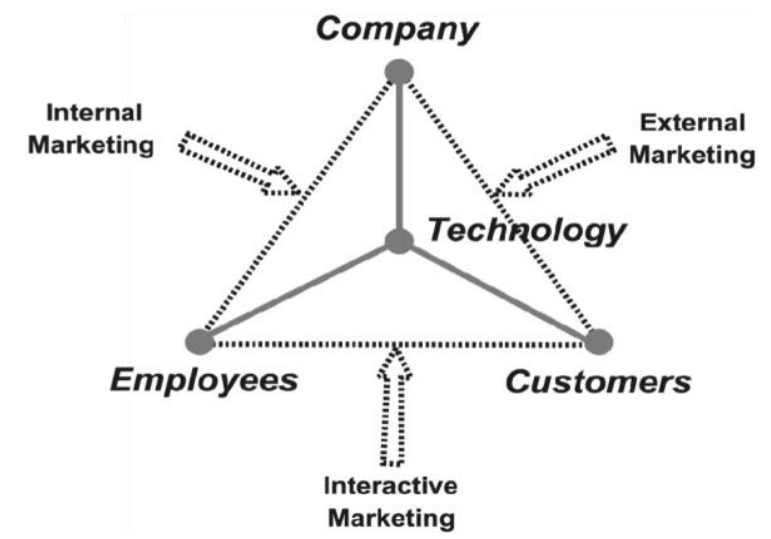

Figure 1: The service triangle (Rao, 2004)

\subsection{Considering customer as the king}

The prominence of customer satisfaction cannot be exaggerated. Without customers the firm has no reason to exist every service business needs to productively define and measure customer satisfaction. Waiting for customers to complain in order to problems in the service delivery system or giving the firm's progress in customer satisfaction based on the number of complaints received is inexperienced. However, the importance of customer satisfaction is defined by Zairi (2000) as "Customers are the purpose of what we do and rather than them depending on us, we very much depend on them. The customer is not the source of a problem; we shouldn't make a wish that customers would go away because our future and security will be put in jeopardy"

"If the product matches expectations, the consumer is satisfied; if it exceeds them, the consumer is highly satisfied; if it falls short, the consumer is dissatisfied" (Kotler et al., 2008). This is a relative concept of customer expectation and performance of the product or service offered. Hoyer and Macinnis (2001) say that the satisfaction is a correlation of state of mind of happiness, receiving, break, enthusiasm and enjoyment. A satisfied customer makes a positive impact on the profitability of the business, as this leads to repeat purchase, brand loyalty and positive word of mouth (Hoyer and Macinnis, 2001).

Customer expectations can also be well-defined as buyer's partial benefit about a product. Expectations are desires and wants of customers which means what they feel a service product should provide these are formed in a basis of past experience with the firm and its competitors and marketing mix inputs. Expectations are more specifically related to the components of the marketing mix which may be extended in the services sector to include physical evidence, process and people. (Booms and Bitner, 1981) A customer with high experience of quality will perceive the quality of a service as poorer compared to one with lower expectations. This mean that a customer may have low expectations based on earlier experience with the service provider; if those expectations are met there is no gap and service quality is considered satisfactory (Booms and Bitner, 1981). 
Webster defines this as "an actual living through an event, anything observed or lived through all that has happened to one". (Webster, 1983) An Experience can be defined by "The apprehension of an object thought, or emotion through he senses or mind", active participation in events of activities leading to the accumulation of knowledge or skill" (www.dictionary.com).

In a business environment "Experiences occur whenever a company intentionally uses services as the stage and goods as props to engage an individual" (Gilmore, 1999). According to the view point of Ali Araghchi, (service quality, customer satisfaction, customer experience and behavioral intention in Iranian retail stores, 2008) customer experience can be categorized to five main components.

* Sense experience - This deals with the five sensors known as sight, touch, taste, smell as customer value creation components.

* Feel experience - This deal with the inner feelings and emotions of the customers where a positive experience links to a product to solid feelings of happiness and egotism.

* Contemplate experience - This deal with creating values for customers by nagging them creatively.

* Act experience- This deals with generating importance for clients by presenting another lives, behaviors in doing business.

* Relate experience- This deals with social experiences, social identity and sense of belonging. $\mathrm{He}$ in his article further explained that, "experience in contrast is process oriented, clearly experience provides much more guidance because it forces you to identify the details that result in satisfaction, if you go through the process of managing the customer experience, satisfaction is likely to be one of the results."

The three stages of constrains of an experience defined by O'Sullivan and Spangler (1998), analyzed "events or feelings that occur prior, during, and after participation".

Components of experience according to Knutson et al. (2003) is that, "Identifying the extents of the knowledge concept: development mode".

1. Pre experience -whatever involved in prior to the actual contribution in the involvement itself.

2. Participation- The actual connection in the experience

3. Post experience- the aftermath participation.

Altogether, when analyzing the customer experience has the simultaneous exposure mentioned as above and varies with one to another customer (Knutson et al., 2003).

\subsection{Evidence from recent research}

The service delivered in terms of education is highly intangible and depends on the provider (teacher) and consumed by customers (students). According to a recent investigation of Hameed and Amjad in 2011, it has found that the quality rendered in higher educational institutions' cannot be objectively measured due to complexity and diversity (Hameed and Amjad, 2011).

Conversely, the recent studies also have identified that Total Quality Management (TQM) is a comprehensive approach for quality management as it highly focus on customers, continuous improvement, strategic management, employees and importance of quality assurance system in higher education sector (Yang, 2012).

\section{RESEARCH METHODOLOGY}

The proposed study intends to use a qualitative approach where the survey based questionaries' are used in measuring the service superiority. The survey contained statements grounded on, the five SERVQUAL dimensions offered by Parasuraman et al. (1985) made-to-order detailed service quality necessities of the private secondary schools. Based on the above literature review the below model being used throughout this research. 


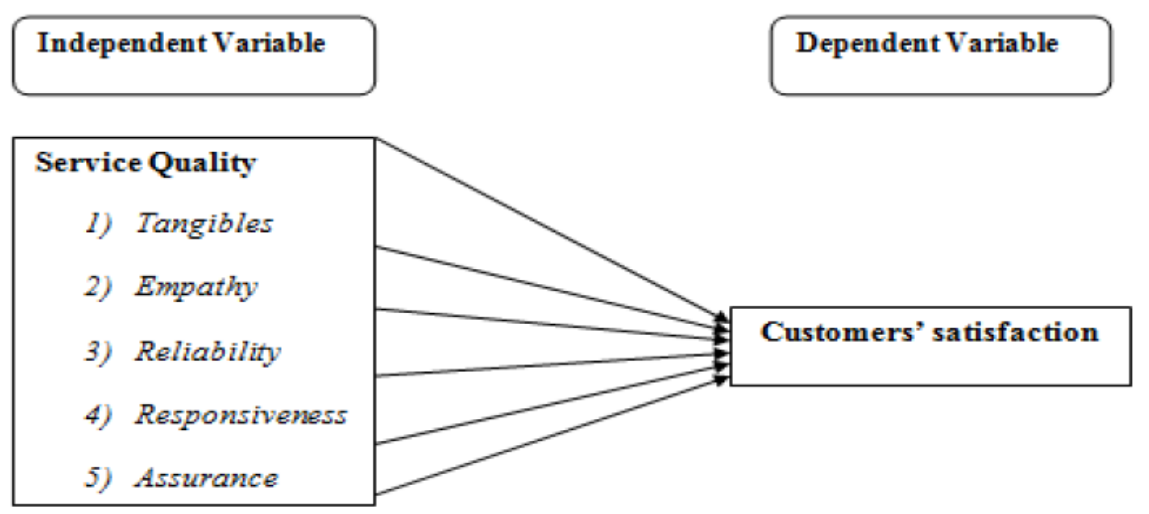

\section{Figure 2: The Conceptual Framework}

The independent variables can be identified as "Service Quality" which has 5 dimensions as described above. According to a study of Parasuraman et al. (1985), the five dimensions of the quality are reliability, responsiveness, tangibles, assurance, and empathy. The dependent variables can be identified as "student satisfaction". By using the 5 point Likert scale mean values this can be further more analyzed as well as the correlation coefficient and regression analysis also been used. All five dimensions will be analyzed in this research.

\subsection{Selection of participants}

This proposed study used the simple random sampling method where the participants of the selected main schools participated to give the feedback. The sample size is 400 students mainly focusing students of the selected private school. The simple random sampling method been used because the students were final consumers of the rendered service and they receive an equivalent chance to catch specific on the selected sample.

\subsection{Data collection method}

This study is based on the quantitative data collection method. Hence the survey method and questionnaire being used to collect the data as primary data collection method. Altogether 500 questionnaires were distributed to the students but only 400 questionnaires were analyzed due to complete submissions. The response rate was $80 \%$ from the selected sample of 500 students. The Secondary data were collected through the annual reports, central Bank reports and the previous researcher's details. This secondary data helped to understand and define the problems clearly.

\subsection{Data analysis and findings}

In here the questions which represented the above given conceptual framework variables being analyzed using the percentage analysis. The conceptual framework independent variables were analyzed through questionnaire's which is attached in the appendix. Here these variables being represented as follows. The question no $1-5$ refer to the tangible segment. Question No $6-10$ refer to the reliability, question no $11-15$ refer to the responsiveness, question no $16-20$ refer to the assurance, question no $21-25$ refer to the empathy, question no $26-30$ refer to the student satisfaction which is the dependent variable. The analysis being done using a 1 to 5 Likert scale. 5 representing strongly agree and 1 representing strongly disagree.

According to researcher it was defined as, the variety of $1 \% \leq$ point's $\geq 34 \%$ is mentioned as small. The variety of $34 \% \leq$ point's $\geq 67 \%$ is expected as reasonable. The variety $67 \% \leq$ point's $\geq 100 \%$ is mentioned to as great or extraordinary. 


\subsection{Analyzing the service quality and the students level of satisfaction}

Based on the SERVQUAL model;

\subsubsection{Tangibles}

Table 1: Analysis of the tangible variable perceived by students

\begin{tabular}{lcc}
\hline Tangible & Number of Customers & Percentage \\
\hline Low $(1=\mathrm{T}>34)$ & 200 & $50 \%$ \\
Moderate $(34=\mathrm{T}>67$ & 150 & $37.5 \%$ \\
High $(67=\mathrm{T} \geq 100)$ & 50 & $12.5 \%$ \\
\hline
\end{tabular}

According to the above Table 1, among 400 students, 50 of them indicating $12.5 \%$ are highly perceived in the rendered tangibility of service. Furthermore 150 indicating $37.5 \%$ are moderately perceived in their tangibility of the service. The rest of 200 students which are $50 \%$ evidence on low perceived tangibility of the service. In conclusion, most of the students do not perceive any tangibility in the rendered service including proper facilities, value for money, technology so staff members physical appearance, cleanliness, updated technology, physical facilities should be furthermore improved which shows another major finding from the analysis been done.

\subsubsection{Reliability}

Table 2: Analysis of the reliability variable perceived by students

\begin{tabular}{lcc}
\hline Reliability & No of Customers & Percentage \\
\hline Low $(1=\mathrm{RL}>34)$ & 98 & $24.5 \%$ \\
Moderate $(34=\mathrm{RL}>67)$ & 102 & $25.5 \%$ \\
High $(67=\mathrm{RL} \geq 100)$ & 200 & $50 \%$ \\
\hline
\end{tabular}

According to the above Table 2, while analyzing the Reliability of perceived service quality of the school, among 200 students, indicating 50\% are highly perceived on the reliability of the given service by the school. This indicates that they are aware on the past track records about the good results already achieved by the school and are keeping faith on the school. In here 102 students, which are $25.5 \%$ are moderately perceiving reliability of service. The rest of the 98 customers which is $24.5 \%$ are having a low perspective on reliability of the service. As a major finding of the research this school already reflects that they provide a reliable service where the students are keeping more faith on the school due to better results of the previous years. Thus this should be furthermore improved as providing the promised levels of resources and facilities are a must and not rendering it may cause the loss of both students and parents' goodwill on the school which means a great loss to the school.

\subsubsection{Responsiveness}

Table 3: Analysis of the responsiveness variable perceived by students

\begin{tabular}{lcc}
\hline Responsiveness & No of Customers & Percentage \\
\hline Low $(1=\mathrm{RP}>34)$ & 138 & $34.5 \%$ \\
Moderate $(34=\mathrm{RP}>67)$ & 133 & $33.25 \%$ \\
High $(67=\mathrm{RP} \geq 100)$ & 129 & $32.25 \%$ \\
\hline
\end{tabular}

According to the above Table 3, here 138 students representing $34.5 \%$ clearly states that the school administration body and the teachers are very low with regard to the responsiveness in delivering their service. They are not strict with the deadlines of the school with regard to paper marking and assessment evaluation. Conversely, $33.25 \%$ of the student population explains that the condition is moderate and the school administration is moderately responsive with their need fulfillment. 
Furthermore, 129 of the students indicating $32.25 \%$ strongly believe that responsiveness of the school staff is high with regard to their needs. As stated in the literature review responsiveness dimension is another SERVQUAL dimension. This variable elaborates that the organization should never be too busy to respond, employees should tell exact time of services, and the employees should be always willing to help the customers. By considering the given analysis it is explicit that the company currently have not achieved a good status in this aspect where delays and waiting time in providing facilities as well as supportiveness of the staff in different situations for students are comparably bad.

\subsubsection{Assurance}

Table 4: Analysis of the Assurance of perceived service of students

\begin{tabular}{lcc}
\hline Assurance & No of Customers & Percentage \\
\hline Low $(1=\mathrm{RP}>34)$ & 72 & $18 \%$ \\
Moderate $(34=\mathrm{A}>67)$ & 255 & $63.75 \%$ \\
High $(67=\mathrm{A} \geq 100)$ & 73 & $18.25 \%$ \\
\hline
\end{tabular}

According to the above Table 4 while examining the assurance of perceived service quality of the students, among 73 indicating $18.25 \%$ are extremely supposed in assurance and 255 amounting $63.75 \%$ have moderate idea on the assurance variable of the school. Similarly, a very low amount of students indicating $18 \%$ have a very low assurance perspective regarding the school. So this school as a major finding should improve politeness and hospitality qualities within staff members by proper training and development programmes, workshops etc. safety conditions should also take into consideration whereas the emergency reactions, first aid, ambulance services, proper schedules, deadlines and special attention towards weak and disable students should be taken into consideration.

\subsubsection{Empathy}

Table 5: Analysis of the Empathy on perceived service

\begin{tabular}{lcc}
\hline Empathy & No of Customers & Percentage \\
\hline Low $(1=\mathrm{RP}>34)$ & 365 & $91.25 \%$ \\
Moderate $(34=\mathrm{E}>67)$ & 10 & $2.5 \%$ \\
High $(67=\mathrm{E} \geq 100)$ & 25 & $6.25 \%$ \\
\hline
\end{tabular}

According to the above table 5 while examining the empathy variable of perceived service quality 25 students, indicating $6.25 \%$ from the total population described that empathy towards them from the staff and school administration is low.2.5\% are having a moderate perspective on the rendered service quality by the school. Conversely, 365 of the students said that school administration is not paying much attention on empathy variable resulting $91.25 \%$ out of the total population. As a major finding Individualized attention given to each student and reactions towards emergency situations are low which is another major finding from the analysis been done.

\subsubsection{Customer satisfaction}

Table 6: Analysis of the client satisfaction on perceived service

\begin{tabular}{lcc}
\hline Customer Satisfaction & No of Customers & Percentage \\
\hline Low $(1=\mathrm{CS}>34)$ & 73 & $8 \%$ \\
Moderate $(34=\mathrm{CS}>67)$ & 250 & $74 \%$ \\
High $(67=\mathrm{CS} \geq 100)$ & 77 & $18 \%$ \\
\hline
\end{tabular}

According to the above table 6 while examining the entire alleged customer satisfaction of the school, among 77 students indicating $18 \%$ are highly satisfied on perceived service. Similarly, $74 \%$ is moderately satisfied with the service and only $8 \%$ are completely dissatisfied which is inexcusable. 
Overall, result is that moderately satisfied students are high with comparison to totally dissatisfied crowd which is $66 \%$ greater in this study.

\section{AREAS FOR FUTURE RESEARCH}

Education sector is a rapidly growing niche market in Sri Lanka. Further research on the customer satisfaction of education services provided by the secondary schools in Sri Lanka can be carried out using a larger sample size which would increase the possibility of statistically detecting any patterns or differences in data.

The current research is conducted only taking the view points of the students but the same study can be expanded towards the perspectives of staff (teachers), administrative body, parents etc. This research excludes the opinion of back up or support staff who also considered as a part of the process of service delivery. A study including views of customers, management, frontline staff, support staff and service suppliers would provide a more complete picture. Also perception is not static, research and surveys be performed regularly in order to reassess service quality levels in secondary schools. In fact schools do not have the choice than reassess and review service quality constantly in order to retain their existing students or to attract new ones. Customers are ruthless and quite demanding. If it want to remain and succeed in business, they should understand what their customers want and what they perceive as service quality.

\section{LIMITATIONS OF THE STUDY}

The study examined experienced and perceived quality levels are individual and subjective to issue. The SERVQUAL instrument used was adopted and shortened for convenience of the research thus affects validity and reliability in data. The accuracy of the measurement are limited to the 5 variables been examined. However the other variables which effects such as price, promotion etc. were not considered.

\section{CONCLUSION}

This is an era of competitive service industries which has resulted in an increased interest in service quality. This is especially true for educational sector where service to students are interactive and labor intensive. The main focus in the service competitions is the management of moments of truth between customers and employees, and the creation of adequate support from managers, to create value for customers. The presented research aims in improving the quality levels been provided to students in achieving their educational targets. As service is intangible and subject to measure exactly, in order to provide quality service it is essential that there should be an alignment in the values and perceptions of the customers with those staff delivering the service and the managers provide the service specifications. The research identified areas to be improved that enhances the future levels of service quality. So by paying more attention towards the variables which has a low regression values has to be improved in order for the customers to be satisfied as well as for company quality improvement. This research has not only opened the door for more work in this area but also has made the managers aware of the need to check the alignment of perception align the value chain in order to provide better service.

\footnotetext{
Funding: This study received no specific financial support.

Competing Interests: The author declares that s/he has no conflict of interests.

Contributors/Acknowledgement: The authors declared that they have no conflict of interests.

Views and opinions expressed in this study are the views and opinions of the authors, Asian Journal of Empirical Research shall not be responsible or answerable for any loss, damage or liability etc. caused in relation to/arising out of the use of the content.
} 


\section{References}

Booms, B. H., \& Bitner, M. J. (1981). Marketing strategies and organization structures for service firms. Marketing of Services, J. Donnelly and George Chicago: American Marketing, 47-51. view at Google scholar

Dotchin, J. A., \& Oakland, J. S. (1994). Total quality management in services: Part 1: Understanding and classifying services. International Journal of Quality \& Reliability Management, 11(3), 926. view at Google scholar / view at publisher

Education, M. O. (2016). Ministry of Education. [Online] Availableat: http://www.moe.gov.lk.

Gilmore, T. D. (1999). Customer satisfaction in the hotel industry: Meaning and measurement. The Experience Economy - Work Is Theatre and Every Business Is a Stage. Harvard Business School Press, Boston, MA. view at Google scholar

Gronroos, C. (1990). Service quality: The six criteria of good perceived service quality. Review of Business, 9(3), 10-13. view at Google scholar

Guide, S. L. (2008). Education in Sri Lanka. Colombo: www.justlanded.com.

Hameed, A., \& Amjad, S. (2011). Student's satisfaction in higher learning institutes: A case study of COSMATS Abbottabad, Pakistan. Iranian Journal of Management Studies, 4(1), 144-162. view at Google scholar

Hoyer, W. D., \& MacInnis, D. J. (2001). Consumer behavior. 2nd ed., Boston, Houghton Mifflin Company. view at Google scholar

Knutson, B., Beck, J., \& Jeffrey, A. (2003). Identifying the dimensions of the guest's hotel experience. Cornell Hospitality Quarterly, 50(1), 44-55. view at Google scholar / view at publisher

Kotler, P., Armstrong, G., Wong, V., \& Saunders, J. (2008). Principles of marketing. 5th ed. Harlow: Pearson. view at Google scholar / view at publisher

O'Sullivan, E. L., \& Spangler, K. J. (1998). Experience marketing: Strategies for the new millennium. State College, PA: Venture Publishing. view at Google scholar

Parasuraman, A.,Valarie, Z., \& Leonard, B. (1985). A conceptual model of service quality and its implication for future research (SERVQUAL). Journal of Marketing, 49(4), 41-50. view at Google scholar / view at publisher

Rao, C. (2004). Services marketing. 3rd ed. New Delhi: Dorling Kindersley (India) Pvt Ltd. view at Google scholar

Webster, J. (1983). Webster's new universal unabridged dictionary. Cleveland, OH: Simon and Schuster, 136-142. view at Google scholar

Yang, Y. (2012). The integration of TQM and six-sigma. Total quality management and six sigma. Rijeka: InTech. view at Google scholar / view at publisher

Zairi, M. (2000). Managing customer dissatisfaction through effective complain management systems. The TQM Magazine, 12(5), 331-335. view at Google scholar / view at publisher 


\section{Appendix}

\section{Questionnaire for students}

\begin{tabular}{|c|c|c|c|c|c|}
\hline & $\begin{array}{c}\text { Strongly } \\
\text { Agree }\end{array}$ & Agree & Neutral & Disagree & $\begin{array}{l}\text { Strongly } \\
\text { Disagree }\end{array}$ \\
\hline $\begin{array}{l}\text { 1. This school have modern } \\
\text { technological equipment }\end{array}$ & 5 & 4 & 3 & 2 & 1 \\
\hline $\begin{array}{l}\text { 2. The basic facilities of the school } \\
\text { is good. }\end{array}$ & 5 & 4 & 3 & 2 & 1 \\
\hline 3. The teachers are highly qualified & 5 & 4 & 3 & 2 & 1 \\
\hline $\begin{array}{l}\text { 4. Modern teaching methods are } \\
\text { rendered. }\end{array}$ & 5 & 4 & 3 & 2 & 1 \\
\hline $\begin{array}{l}\text { 5. The appearance of the staff is } \\
\text { good }\end{array}$ & 5 & 4 & 3 & 2 & 1 \\
\hline $\begin{array}{l}\text { 6. Student registration work is on } \\
\text { time }\end{array}$ & 5 & 4 & 3 & 2 & 1 \\
\hline $\begin{array}{l}\text { 7. Prompt reaction of each and } \\
\text { every department in the school. }\end{array}$ & 5 & 4 & 3 & 2 & 1 \\
\hline $\begin{array}{l}\text { 8. The staff is capable in delivering } \\
\text { an error free service }\end{array}$ & 5 & 4 & 3 & 2 & 1 \\
\hline $\begin{array}{l}\text { 9. The teachers are strict with } \\
\text { deadlines given in assignment and } \\
\text { paper marking }\end{array}$ & 5 & 4 & 3 & 2 & 1 \\
\hline $\begin{array}{l}\text { 10. Staff is capable in proper conflict } \\
\text { handling. }\end{array}$ & 5 & 4 & 3 & 2 & 1 \\
\hline $\begin{array}{l}\text { 11. Waiting time is high for releasing } \\
\text { the paper marks }\end{array}$ & 5 & 4 & 3 & 2 & 1 \\
\hline $\begin{array}{l}\text { 12. Supportiveness of the teachers are } \\
\text { good }\end{array}$ & 5 & 4 & 3 & 2 & 1 \\
\hline 13. Individualized attention & 5 & 4 & 3 & 2 & 1 \\
\hline $\begin{array}{l}\text { 14. On time facilities without any } \\
\text { delay }\end{array}$ & 5 & 4 & 3 & 2 & 1 \\
\hline $\begin{array}{l}\text { 15. Proper guidance and mentoring } \\
\text { by teachers }\end{array}$ & 5 & 4 & 3 & 2 & 1 \\
\hline $\begin{array}{l}\text { 16. Proper hospitality qualities of the } \\
\text { staff }\end{array}$ & 5 & 4 & 3 & 2 & 1 \\
\hline $\begin{array}{l}\text { 17. Teachers are capable in handling } \\
\text { students }\end{array}$ & 5 & 4 & 3 & 2 & 1 \\
\hline 18. Politeness in language & 5 & 4 & 3 & 2 & 1 \\
\hline 19. Caring with regard to safety & 5 & 4 & 3 & 2 & 1 \\
\hline $\begin{array}{l}\text { 20. Properly trained teachers and } \\
\text { updated teaching methods }\end{array}$ & 5 & 4 & 3 & 2 & 1 \\
\hline 21. Individual attention for students & 5 & 4 & 3 & 2 & 1 \\
\hline $\begin{array}{l}\text { 22. First aid facilities and proper } \\
\text { medical facilities }\end{array}$ & 5 & 4 & 3 & 2 & 1 \\
\hline $\begin{array}{l}\text { 23. Availability of medical } \\
\text { equipment }\end{array}$ & 5 & 4 & 3 & 2 & 1 \\
\hline 24. Special care for disable students & 5 & 4 & 3 & 2 & 1 \\
\hline $\begin{array}{l}\text { 25. Special schedules for weak } \\
\text { students }\end{array}$ & 5 & 4 & 3 & 2 & 1 \\
\hline $\begin{array}{l}\text { 26. I feel that all the services } \\
\text { provided by the school is good. }\end{array}$ & 5 & 4 & 3 & 2 & 1 \\
\hline $\begin{array}{l}\text { 27. Actions are immediately taken by } \\
\text { the top management }\end{array}$ & 5 & 4 & 3 & 2 & 1 \\
\hline
\end{tabular}


Asian Journal of Empirical Research, 8(2)2018: 78-89

\begin{tabular}{llllll}
\hline $\begin{array}{l}\text { 28. Complain handling is good } \\
\text { 29. I accept that in any emergency } \\
\text { situation the school acts fast }\end{array}$ & 5 & 4 & 3 & 2 & 1 \\
$\begin{array}{l}\text { 30. I trust my school in terms of } \\
\text { results when considering the past } \\
\text { results. }\end{array}$ & 5 & 4 & 3 & 2 & 1 \\
\hline
\end{tabular}

